find considerable use as toxic agents in insecticides, especially in fruit growing; the applications of these oils in the leather and textile industries are probably better known than the growing use of hydrogenated fish oils in the manufacture of tinplate; they can be transformed into rubber substitutes as well as into varnishes or linoleum.

The wide range of utility of the marine animal oils, potential as well as actual, is extremely thoroughly covered in a recent Bulletin edited by Dr. Brocklesby*; but the work can be commended for other reasons which will appeal to readers of NATURE. Instead of being limited to the purely technical aspects, the discussion of the latter is based entirely upon the fundamental chemical and physical properties of the fats, which are dealt with so adequately that the book forms a remarkably complete guide to the

* The Chemistry and Technology of Marine Animal Oils with particular reference to those of Canada. Bulletin 59 of the Fisheries Research Board of Canada. Edited by Dr. H. N. Brocklesby (Chief figures. (Ottawa: Fisheries Research Board of Canada, 1941.) 44 dollars (paper), 3.80 (cloth) net. chemistry of fats as a whole. Moreover, the component acids and glycerides of the marine animal oils are considered in the light of modern research in this field (to which the chemists of the Pacific Fisheries Experimental Station have made their own contributions) and not solely with reference to the technically useful, but otherwise often uninformative, 'analytical characteristics'such as iodine values, specific gravities, etc.

The late Sir William Hardy, first director of Food Investigation of the Department of Scientific and Industrial Research, planned that the work in his research stations should involve equally the technical applications of science and the fundamental principles underlying these applications--a tradition which is still followed by the Food Investigation Board. It is evident that the balance between 'pure' and 'applied' science is similarly maintained by the Canadian Fisheries Research Board ; in consequence the monograph now published will be read with as much interest and benefit by other scientific workers as by the technologists for whom it is primarily intended.

\title{
ELECTRIC HEATING OF BEEHIVES
}

T HE British Electrical and Allied Industries Research Association has issued a preliminary report, by its director and secretary, Mr. E. B. Wedmore, describing experiments on the heating of beehives*. It also describes the construction and preliminary testing of certain units for keeping beehives at any required temperature. Tests are to be made shortly at the Rothamsted Experimental Station under working conditions on a large scale.

In Nature, the heat required by a colony of bees is produced by the consumption of honey. This is an expensive fuel, and might be helped out and controlled to advantage by the use of electricity. Many observations of temperatures within the hive in relation to the life and requirements of the bee have been made, and the craft has turned in the direction of controlled heating of hives. The aim of the present report is to bring the problem into perspective and to record some preliminary observa. tions on effects within the hive of changing external temperatures and conditions, and of the use of certain heating units.

In obtaining figures of convenient magnitude, and in considering electric heating, it is convenient to measure all energy in electrical terms. The complete combustion of $1 \mathrm{lb}$. of an average honey with an average water content represents two watts for one month, and honey in the hive may be taken as being worth $6 d$. per lb. (If removed, extracted, strained, bottled, packed and carted, it may be worth, say, 1s. $4 d$. wholesale.) Thus the production of heat by the complete combustion of honey costs $3 d$. per watt per month if the efficiency is 100 per cent. The heat is, in fact, produced by the bees deliberately performing mechanical work, and while the oxygenation is probably fairly complete, there is wear and tear to be made good as well as shortening of the bees'

* British Electrical and Allied Industries Research Association Technical Report, Reference W/T5 : Electric Heating of BeehivesPreliminary Report. By E. B. Wedmore. Pp. $19+5$ plates. (London British Electrical and Allied Industries Research Association, 1941.) British $6 d$. life, so that the actual cost per watt per month to the beekeeper must be higher, but most probably less than twice $3 d$.

If sugar is used, the heat of combustion is about doubled, but if reduced to syrup by adding water, this additional water content has to be dealt with. The physiological loss is greater and the syrup has to be prepared. Taking the sugar syrup at $6 \dot{d}$. per lb. of sugar including labour and wastage in storing, the cost per watt per month will be between $1 \frac{1}{2} d$. and $3 d$., not allowing for maintenance of and interest on the cost of apparatus.

Electrical energy could be substituted for honey consumption only if the heat be provided at the right time, the right place and in the right quantity. Assuming 100 per cent efficiency in each case, we have then for the cost of 1 watt per month : (a) by consumption of honey in the hive at $6 d$. per lb., $3 d$. ; (b) by consumption of sugar in the hive at $4 d$. per per lb., 1 $\frac{1}{2} d . ;$ (c) by use of electrical energy at $1 d$. per unit, $\frac{3}{4} d$. It is clear, therefore, that there must be some definite additional indirect gain if heating by electricity is to be justified, the cost of the equipment must be low and the technique of its use simple and efficient.

With the commencement of frosts in October, breeding is greatly reduced, and it ceases in December or earlier. Bardenbacher's tests suggest that brood raising may be advanced about three weeks by appropriate heating in the spring season, and one such advanced colony may well do the work of two. It is pointed out that in spring there are good hopes of stimulating brood raising by making it easier for the bees to maintain the requisite temperature, especially at night and in cold periods, and at the same time reduce the indirect losses caused by condensation of moisture.

Data as to the thermal properties of a hive and its contents are given. The hives are usually constructed of cedar or firs of varying quality, and some are painted. Probably reduction of forced movement of 
air within the hive in really cold weather by guarding the entrance is more important than any external packing.

To obtain currents of 1-20 watts from a 230 -volt circuit requires resistances which, if wire-wound and suitably insulated, are relatively costly. On the other hand, two miniature lamps of suitable rating in series will give results of the right order at a moderate cost with reasonable life, and will admit of wiring a number of hives in parallel off a mained loop from hive to hive.

The hive used for preliminary experimental work consisted of a standard National body on a base with deep cover, a 6-in. lift being used to carry the heating units and packing so that the deep cover just overlapped the top of the body box. The hive was located in a well-ventilated wooden shed to protect it from winds. In certain tests a small fan was used to blow a stream of air at a speed of about 12 m.p.h. diagonally at the entrance. The hive used represents roughly the minimum size of stock hive that would be employed for wintering in Great Britain.

It has been shown that a small increase in the difference between the internal and external tem. peratures of the hive has a useful effect in reducing condensation and consequent dampness. Two periods have to be considered, namely, the quiescent period and the early brood-raising period. The useful applications already made belong to the early broodraising period; the difficulties met with are mainly difficulties of control.

Twenty-four heating units are being built for Rothamsted Experimental Station, where they will be used with and without thermostatic control during next winter.

\section{FORTHCOMING EVENTS}

\section{Monday, May 5}

Royal Society of Arts (at John Adam Street, Adelphi, London, W.C.2), at 2.30 p.m.-Dr. G. Stafford Whitby : "Chemotherapy", II.

British Psychological Society (at 55 Russell Square, London, W.C.1), at 1.20 p.m.-Mrs. Winifred Raphael : "War-Time Grouses in Industry".

\section{Thursday, May 8}

Institution of Electrical Engineers (at Savoy Place, London, W.C.2), at 2.30 p.m.-Prof. S. Chapman, F.R.S. : "Electrical Works by Helios, or The Sun and the Ionosphere".

\section{Friday, May 9}

Geologists' Association (at the Geological Society of London, Burlington House, Piccadilly, London, W.1), at 5.30 p.m.-Mr. C. E. N. Bromehead: "The Early History of Mining".

\section{APPOINTMENTS VACANT}

APPLICATIONS are invited for the following appointments on or before the dates mentioned:

Thacher of ENGINhering Workshop Practich and/OR WoODWORK AND DRAWING, and a TEACHER OF MATHEMATICS AND ScIRNCE,
at the Mexborough Schofield Technical Institute-The Secretary to at the Mexborough Schofield Technical Institute-The Secretary
the Managers, Education Offlce, Mexborough, Yorks. (May 10).

Senior assistant Master to teach Science and Mathematics at the Sparkhill Commercial School-The Chief Education Officer, Higher Education Department, Education Offices, Council House, Margaret Street, Birmingham 3 (May 12).

PRINCIPAL of the Shrewsbury Technical College-The Secretary, for Education, County Buildings, Shrewsbury (May 21).

Professor of Mechanicat, ENGINERRING-The Registrar, Universitv of Sydney, Sydney, N.W.S., Australia (June 1).

\section{REPORTS AND OTHER PUBLICATIONS}

(not included in the monthly Books Supplement)

\section{Great Britain and Ireland}

University College of Wales, Aberystwyth: Welsh Plant Breeding Station. War Food Production Advisory Bulletin No. 2: Ley-Farming. By Sir R. George Stapledon. Pp. 22. (Aberystwyth: Welsh Plant Breeding Station.) 18.

Spectrochemical Abstracts. Vol. 2, 1938-1939. By Ernest H. S. van Someren. Pp. 38. (London: Adam Hilger, Ltd.) [313 Scientific Proceedings of the Royal Dublin Society. Vol. 22 (N.S.), No. 37: Studies in Peat, Part 10: Activated Charcoals from Peat Residue. By Dr. Joseph Reilly and James R. O'Donoghue. Pp. 367-377. (Dublin: Hodges, Figgis and Co., Ltd. ; London: Williams
and Norgate, Ltd.) 18.

$[84$

Imperial Forestry Institute: University of Oxford. Sixteenth Annual Report, 1939-40. Pp. 18 . (Oxford: Imperial Forestry

Thirty-eighth Annual Report, 1940-1941, of the Imperial Cancer kesearch Fund. Pp. 34. (London: Royal College of Surgeons.) [94 Proceedings of the Royal Society of Edinburgh. Section A (Mathematical and Physical Sciences). Vol. 61, Part 1, No. 4: On an Elementary Solution of a Partial Differential Equation of Parabolic Type, Part 1. By E. T. Copson. Pp. 37-53. 18. 6d. Vol. 61, Part 1, No. 5: On an Elementary Solution of a Partial Differential EquaE. T. Copson. Pp. 54-60. 6d. (Edinburgh and London: Oliver E. T. Copson. Pp. 54-60. 6d. (Edinburgh and London: Olive
and Boyd.)

Town and Country Planning Association. Forty-second Annual Report. Pp. 8. (Welwyn Garden City: Town and Country Plannin Association.)

British Trust for Ornithology. Seventh Report, for the Year 1940 Pp. 12. (Oundle: British Trust for Ornithology.) [24

\section{Other Countries}

Imperial Council for Agricultural Research. Scientific Monograph No. 14: Further Studies on Cereal Rusts in India. By Dr. K. C. Mehta. Pp. vil $+224+12$ plates. (Delhi : Manager of Publications.) 6 rupees; $98.6 d$.

Union of South Africa: Department of Agriculture and Forestry. Pamphlet No. 222 (Chemistry Series No. 163): The Inoculation of Clover. By W. B. Goldschmidt and Dr. E. R. Orchard. Pp. 8. (Pre-
toria: Government Printer.) 3d.
[24

$[24$

Carvão de Santa Catarina. Relatorio a presentado em 1890 a Governo da Republica pelos Luiz F. Gonzaga de Campos, Fabio Hostilio de Moraes Rego, Joæo Caldeira d'Alvarenga Messeder.' Pp. 91. Duas Notas sobre os Cimentos Nacionais-a Magnesia-os 'Compostos' do Cimento. Pelo Paulo Sá. Pp. 39. A industria e o Laboratorio: o auxilio dos Laboratorios às Industrias de Construç̃o. Pelo Paulo Sá. Pp. 32. A especiflcacão Brasileira para Cimento Portland e as tendências modernas sobre o assunto. Pelo Paulo Sá. Pp. 28. Metalografla das Ligas de Aluminio : alumínio-ferro. Por E. Orosco e Helena Brandăo Orosco. Pp. $16+12$ plates. Estabilizacão de solos. Pelo Paulo Sá. Pp. 51. (Rio de Janeiro: Instituto Nacional de Tecnologia.)

Anuario del Observatorio Astronómico de Madrid para 1941. Pp 300. (Madrid : Instituto Geográflco.) Colony of Mauritius : Department of Agriculture. Tenth Annua Report of the Sugarcane Research Station for the Year 1939. Pp. 48 Mauritius: Government Printer.) 70 cents.

Indian Central Cotton Committee: Technological Laboratory. Technological Bulletin Series A, No. 51 : Technological Reports on Trade Varieties of Indian Cottons, 1940. By Dr. Nazir Ahmad. Pp. vi +107.1 .8 rupees. Technological Bulletin, Series A, No. 52 Technological Reports on Standard Indian Cottons, 1940. By Dr. Nazir Ahmad. Pp; iv +110.1 .8 rupees. (Bombay: Indian Central Cotton Committee.)

Memoirs of the National Academy of Sciences. Vol. 23, Third Memoir: Observations and Measurements on the Members of the National Academy of Sciences. By Ales Hrdlicka. Pp. $x+108$ (Washington, D.C. : Government Printing Office.) 30 cents. $x+111$ Smithsonian Miscellaneous Collections. Vol. 99, No. 19: Notes on Mexican Snakes of the Genus Geophis. By Hobart M. Smith. (Publication 3629.) Pp. ii +6. Vol. 99, No. 20: Further Notes on Mexican Snakes of the Genus Salvadora. By Hobart M. Smith. (Publication 3630.) Pp. ii +12. (Washington, D.C. : Smithsonian Institution.) [114

Punjab Irrigation Research Institute. Report for the Year ending April 1939. Pp. $v+7+189+102$ plates. Research Publication, Vol. 2 , No. 24: Experiments for the Haveli Project on a Model of the Rivers Jhelum and Chenab Downstream of their Confluence. By Dr. N. K. Bose and L. Thakar Dass Gulati. Pp. $58+27$ plates. 1.8 rupees. Research Publication, Vol. 2, No. 25: Experiments for Silt Control on a Model of the Emerson Barrage, Left Undersluices, Left Regulator, with a Part of the River Chenab Upstream. By Dr. N. K. Bose and Thakar Das Ghulati. Pp. $12+26$ plates. 6 annas. Research Publication, Vol. 3, No. 4: The Formation and the Reclamation of Thur Lands in the Punjab. By M. L. Mehta. Pp. $54+17$ plates. (Lahore :
[164 Canada: Department of Mines and Resources: Mines and Geology Branch, Geological Survey. Paper 40-15: Preliminary Map, Grave Flats, Alberta. By B. R. MacKay. 10 cents. Paper 40-16: Preliminary Map, Pembina Forks, Alberta. By B. R. MacKay. 10 cents. Paper 40-19: Preliminary Map, Bearberry, Alberta. By H. H. Beach. 10 cents. Paper 40-20: Preliminary Map, Assinica Lake, Quebec. By G. Shaw. 10 cents. Paper 40-21: Preliminary Map, Mishagomish Lake, Quebec. By G. Shaw. 10 cents. (Ottaws : King's
Printer.) 